\title{
Impact of a simultaneous reduction in fishing subsidies and introduction of efficient management of rents: the case of the Northwest Spanish fleet
}

\author{
Eugenia Merayo ${ }^{1,4, *}$, Staffan Waldo ${ }^{2}$ and Max Nielsen ${ }^{3}$ \\ ${ }^{1}$ Environmental and Natural Resource Economics at the Faculty of Science, University of Copenhagen, Copenhagen, Denmark \\ 2 Department of Economics, Swedish University of Agricultural Sciences (SLU), Lund, Sweden \\ ${ }^{3}$ Institute of Food and Resource Economics, Faculty of Science, University of Copenhagen, Rolighedsvej 25, \\ 1958 Frederiksberg C, Denmark
}

Received 16 February 2017 / Accepted 10 October 2017

Handling Editor: Olivier Thebaud

\begin{abstract}
Subsidies to the fishing sector have long been criticized for fueling over-fishing, and a reduction in subsidies is currently on the agenda in the negotiations within the World Trade Organization (WTO). This article analyzes the role of subsidies and other management measures for Spain, one of the largest fishing nations within the EU. A static bio-economic model is used to analyze the effect of simultaneous elimination of subsidies and introduction of an economically efficient management system for the Northwest Spanish fleet. It is concluded that improvements in management would bring substantial rents to the industry, up to $€ 164$ million, irrespective of subsidy level, but also a reduction in fishing effort of almost $60 \%$. Under a management scheme that maximizes economic rents, elimination of subsidies in the fishery would increase social welfare, induced by a decrease in the equilibrium fishing effort level. However, the impact of subsidies under this scheme is limited.
\end{abstract}

Keywords: Fisheries subsidies / fisheries management / bio-economic model

\section{Introduction}

Almost one-third of global fish stocks are currently overfished and another $50 \%$ are fully fished, which means that the vast majority of fish stocks are exploited above or at the maximum sustainable yield (FAO, 2014). The situation of the stocks is consistent with the stagnation in fish catches since the 1980s (FAO, 2014). It is also estimated that the global fishing fleet is twice the size needed to exploit current fish stocks (World Bank and FAO, 2009). In Europe, around $40 \%$ of the fish stocks are fished above MSY (STECF, 2016a). As a response to the situation, the European Union has agreed reductions in fleet capacity and to reach the MSY for all European fish stocks by 2020 (European Commission, 2013).

In economic research, overfishing and overcapacity ${ }^{5}$ are viewed as consequences of the common-pool nature of

\footnotetext{
*Corresponding author: emegar@hotmail.com

${ }^{4}$ This article is based on her Master's thesis.

${ }^{5}$ Overcapacity is a long-term structural phenomenon and should not be confused with the short-term excess capacity that may occur due to inefficiencies in production capacity.
}

fisheries (see e.g., Hardin (1968) on the Tragedy of the Commons). With a lack of appropriate management systems, it is not possible to exclude fishers from exploiting shared fish stocks. Hence, individual catches affect the potential catches of other fishermen. This competitive scheme creates a pervasive economic incentive to catch as much as possible of the resource, which leads to overfishing, overinvestment, and low profitability in the fishing sector (see e.g., Gordon, 1954). That spills over to land-based industries both up- and downstream from the fishery (Nielsen et al., 2017).

Fishing subsidies of different types have been used by many governments to support the fishing sector and improve the economic viability of fisheries. However, the existence of fishing subsidies may encourage further investments and activity in the fishery (see e.g., FAO, 2014), and thus worsen the problem. Sumaila et al. (2010) estimate global subsidies to be US\$ $25-29$ billion annually, around $30-35 \%$ of the value of total catches. A new negotiation process at the World Trade Organization has recently been announced, with the final purpose of prohibiting harmful subsidies, understood as those that contribute to overfishing and overcapacity. The possibility of a multilateral agreement on the matter is now on the international 
agenda, and the achievement of environmental, economic, development, and trade benefits are indicated as objectives (Joint Statement Regarding Fisheries Subsidies, 2016).

While subsidies might worsen the situation for world fisheries, simply removing them will not solve the underlying problems, since overcapacity and overfishing are primarily due to shortcomings in fisheries management (see e.g., Waldo et al., 2016). Changing management is thus important in the long run to obtain sustainable fisheries. The design of such a management system will depend on the characteristics of local fisheries and on local management objectives, including ecological, economic, and social dimensions (Brady and Waldo, 2009). In this paper, efficient management is defined as a management system maximizing the economic rents from the fishery, i.e., we use the concept "economically efficient management". The economic literature suggests the use of individual transferable quotas (ITQs) as one means of doing this (see e.g., Merayo et al., forthcoming, for an analysis of the Danish ITQ system). However, ITQs might not in themselves produce fully efficient fisheries management of rents (Sumaila et al., 2010). One example is that in order to maximize the rents from fishing, the quotas need to be optimally set, which in the EU context involves a negotiation between the member states. The maximum economic yield (MEY) maximizes economic rents, whereas MSY maximizes catches. MSY is specified as the goal of the Common Fisheries Policy (European Commission, 2013).

This article contributes to the literature by analyzing the impact of simultaneously removing subsidies and introducing an economically efficient management system (MEY as defined above) in Spanish fisheries. Spain is one of the largest fishing nations in the EU and the Spanish fishing fleet operates not only in EU waters, but has a major role in fisheries e.g., within EU's partnership agreements with African countries. Subsidies are available from the European Fisheries Fund (EFF), which was the financial arm of the EU's Common Fisheries Policy (CFP) from 2007 to 2014. During that period, Spain received more than $25 \%$ of the total EFF budget of $€ 1$ billion given to fisheries, fish processing, and aquaculture (European Commission, 2015). Since 2014, the EFF has been replaced by the European Maritime and Fisheries Fund (EMFF). Under this European scheme, the different countries have also been allowed to subsidize their fleets, known as state aid. Spain provided additional funds to the fish harvesting sector during 2013 amounting to $€ 88.6$ million (OECD, 2016).

Using a static bio-economic model, this paper empirically estimates economic returns and employment in the fishery for a set of fishing subsidies scenarios and the simultaneous introduction of an economically efficient management system. This enables an analysis of the relative importance of fisheries management versus fisheries subsidies. The model includes fueltax exemptions, grants for vessel construction and modernization, and subsidies to fund general services. The model takes the average vessel as the subject of the analysis, without explicitly considering the heterogeneity of the fishing industry in terms of e.g., targeted species, remuneration structure, or fuel dependency. In order to reduce this heterogeneity and strengthen the validity of the results, the long-distance fleet is excluded from the analysis and only the domestic fleet that fishes in national and European waters is considered.

The fishing fleet analyzed is located in the Northwest Spain, which includes the autonomous regions of Galicia, Asturias,
Cantabria, and Basque Country. Spain, in particular this area, has a high fishery dependency in terms of employment, measured as the share of general employment represented by the fishing sector (European Commission, 2014). This dependency is even higher today because of the economic crisis from 2008 onward, which increased general unemployment.

This article is organized as follows. The next section provides a brief introduction to the literature on fishing subsidies. In section three, an overview of the Northwest Spanish fishery is provided and in section four the methodology used is explained. Section five presents the data. In section six, the results of the analysis are presented and short- and long-run socioeconomic consequences are discussed. Finally, section seven presents some conclusions.

\section{Fishing subsidies}

According to OECD (2000), subsidies can be divided into three main categories: direct payments, cost-reducing transfers, and general services. Direct payments increase the revenue of the fishers and are transferred directly to them. This category includes price support, grants, buyback programs, income support, and unemployment compensation. Cost-reducing subsidies reduce the input costs of the fleet and include fueltax exemptions, subsidized loans, and tax deductions. General services include indirect transfers to the fishing industry, which reduce capital and operating costs. They include costs of management, research, and infrastructure.

In the literature, other authors explore the possible appropriateness of fishing subsidies. For example, Sumaila et al. (2010) divide subsidies into three categories: beneficial, capacity-enhancing, and ambiguous, depending on their impact on fishing capacity. They consider that funds dedicated to management and research, those included in general services by OECD (2000), are beneficial, while fuel-tax exemptions and grants may encourage further capacity increases, and consequently are considered prejudicial in fisheries with overexploitation and overcapacity. However, the effects of subsidies on the decommissioning of vessels, also known as vessel buyback programs, remain ambiguous. In the short run they might reduce overcapacity, but if maintained in the long run, fishers plan their exit after them, potentially leading to further overfishing. Another distinction between "good" and "bad" subsidies, depending on their positive or negative effect on social welfare, is made by Squires et al. (2014). A good subsidy would be, for example, funding to encourage a positive externality, such as technological and R\&D investments. From this perspective, subsidies under general services may be justified. However, in this paper we do not treat general service subsidies as beneficial per se (see Arnason (2000) for a discussion on general services subsidies), but include them in the analysis as any other subsidy.

Empirically, fuel-tax exemption subsidies have attracted considerable attention. A fuel-tax exemption means that fisheries (and other productive sectors that have fuel-tax exemptions) do not pay fuel taxes that are paid by the public. ${ }^{6}$

\footnotetext{
${ }^{6}$ In Spain, fishers purchase generally tax-free fuel, while the fuel providers to the fishing sector are either exempted from paying fuel taxes or obtain refunds of the tax a posteriori (Spain, Law 38/1992 of Special Taxes, of 28 December).
} 
Table 1. General data on the Spanish fish harvesting sector by region, 2014 (Subsidies 2013; € million; *estimated).

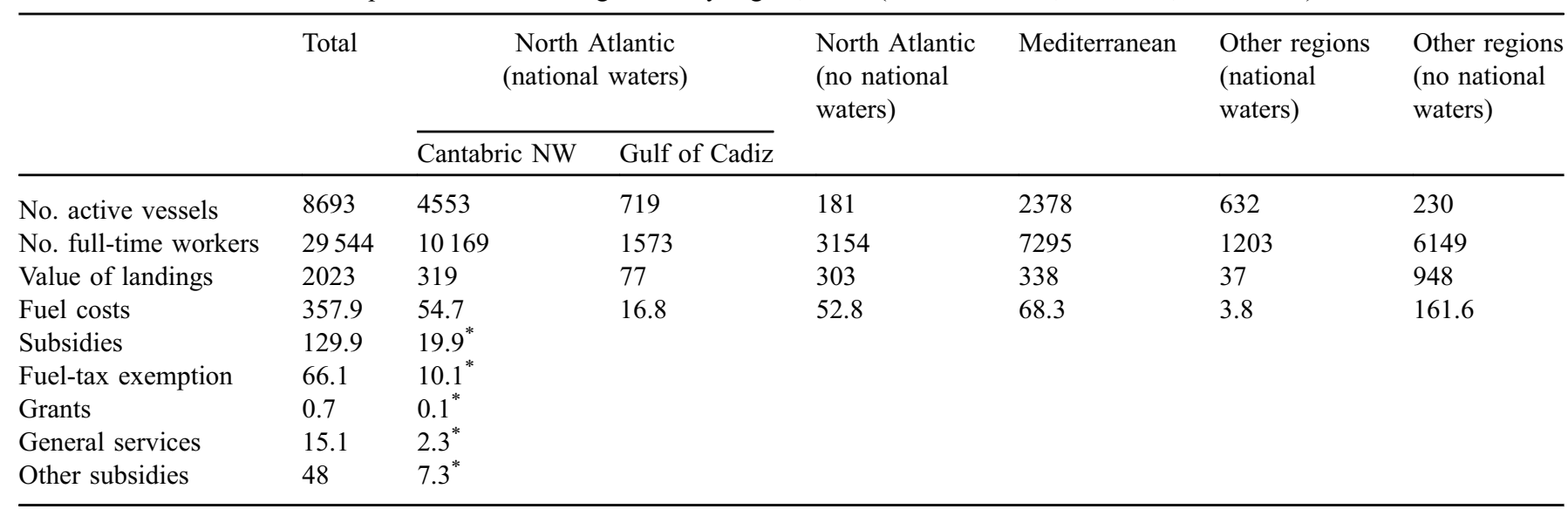

For example, Waldo et al. (2016) shows that fisheries management solving the open access problem would have a major impact on fuel consumption, and thereby $\mathrm{CO}_{2}$ emissions, in Nordic fisheries. Removing fuel-tax exemptions in this situation would have only minor effects on emission levels. Waldo and Paulrud (2016) analyze Swedish fisheries and show that efficient fisheries management under the current catch quotas would have a major impact on $\mathrm{CO}_{2}$ emissions. In the case of decommissioning subsidies aiming at reducing fleet capacity, the empirical literature shows that these are seldom efficient in achieving decommissioning objectives (see e.g., Holland et al., 1999; Minnegal and Dwyer, 2008; Pascoe et al., 2012; and Cordón and Garcia, 2015, for a Spanish example).

\section{The case of the Northwest Spanish fishery}

The Northwest Spanish fleet, which operates in national and European grounds, is studied in this paper. It includes, from west to east, the coastal autonomous regions of Galicia, Asturias, Cantabria, and Basque Country. It has access to the Northeast Atlantic to the west and the Cantabrian Sea to the north. The diversity and fertility of Cantabrian fishing grounds has promoted the establishment of a great number of coastal settlements that have traditionally depended on fish harvesting and processing for their living (Losada, 2000). However, the importance of fisheries in the region might not only be as a source of income and employment, but also as a cultural and identity factor (Freire and García, 2000).

Nowadays, the regions in the area still have a significant socioeconomic dependency on fisheries, measured by the share of fishing employment in relation to general employment, from low-moderate in Basque Country and Asturias to high-very high in Galicia (European Commission, 2014). There are almost 13000 people directly employed in the fishing sector in the area, which corresponds to more than 10000 full-time jobs and represents half of the total fishers in Spain (MAGRAMA, 2014a).

Table 1 shows some general data on the Spanish fishery sector, total and by fishing region, together with data on total fishing subsidies for the Spanish fleet.
The Galician fleet accounts for more than $90 \%$ of the Northwest sector. Most vessels are artisanal (90\%), defined as vessels using traditional and artisanal fishing methods (such as traps and hooks) targeting a variety of different species, and $10 \%$ of the fleet consists of seines and trawlers (MAGRAMA, 2014a). The average vessel has 2.8 fishers, a length of around $8 \mathrm{~m}$, a tonnage of $12.5 \mathrm{GT}$, and an engine power of $58 \mathrm{CV}$, and is 31 years old (MAGRAMA, 2014b).

The total value of catches amounts to $€ 319$ million, which is $16 \%$ of the total Spanish catch value (MAGRAMA, 2014b). The main species fished are tuna, hake, blue whiting, anchovy, sardine, and mackerel.

In 2012, the fish processing sector in Spain employed more than 18000 people, and its gross value added reached $€ 1.28$ billion (STECF, 2014). The main species processed are tuna, sardine, anchovy, and horse mackerel. Canned fish represents $40 \%$ of the Spanish fish processing sector. Galicia, which falls within the area of study, produces $80 \%$ of Spanish canned fish production, both in volume and value (Vieites, 2014).

Although subject to the CFP, the Spanish central government has authority over national sea fishing and thus has the capacity to establish basic legislation regarding management and control of the fishery. The autonomous communities can also adopt regulations that complement those of the central state. An important feature of fisheries management in the area are the cofradias, organizations of fishers of long tradition that cooperate with the different autonomous communities in management of the fishing grounds. They can be defined as socio-economic institutions that represent the various interests of fishers and also have an important role in the sale of fish. In Spain, there are 225 different cofradias, of which almost half, 104, are located in the area of study.

The Northwest Spanish fishery is regulated by a number of management measures, including minimum landing sizes (Spain, 1995, Royal Decree 560/1995, of 7 April 1995), area closures, seasonal closures, regulation of gear and mesh sizes, and restriction of effort through a limitation on days at sea. In addition, total allowable catches (TACs) are set yearly for the most commercially important species, such as hake, tuna, 
sardine, anchovy, and mackerel. According to the management plans, TACs are determined according to biological criteria and vary from year to year depending on the biomass of the fish stock. In Spain, TACs are distributed either to provinces or individual vessels. For example, for bottom trawlers and seines, in the case of hake, horse mackerel, and Atlantic mackerel quotas are allocated directly to the individual vessels. This distribution is made according to historical catches, number of workers, and tonnage. The quotas for hake can be transferred temporarily to other vessels, but not those for the remaining species (Spain, 2015 Order AAA/2534/2015, of 17 November 2015).

The existing fishing subsidies in the area of study include fuel-tax exemptions (not included in the EFF, but established as state aid $^{7}$ ); funds for decommissioning of vessels; income support and unemployment insurance subsidies; subsidies for general services; and grants for vessel construction and modernization. All of these subsidies are considered in this paper except those for decommissioning of vessels (which are not received by active vessels, but by vessels leaving the fishery) and income support and unemployment insurance subsidies.

\section{Methodology}

A static bio-economic model based on Nielsen et al. (2012), and recently applied in Waldo et al. (2016) and Nielsen et al. (2017), is used to estimate the socio-economic return and fishing effort. This is done for an optimal fisheries management scheme to achieve MEY in the fishery of study, under different subsidy scenarios. Observe that the term 'optimal fisheries management' in this study only refers to solving the open access problem to reach MEY, and does not take distorting effects from subsidies into account. The effect of subsidies is analyzed in the scenarios presented at the end of the section. Thus, when estimating scenarios with optimal management including subsidies, this might not be the overall most economically efficient policy, since subsidies might distort fishers' incentives. However, fisheries management in terms of access to the resource is performed to maximize economic returns in the presence of different subsidy levels. The current socio-economic return obtained in the fishery is calculated to allow for comparison. Fishing effort is also calibrated for each scenario, measured by the number of vessels. Employment in the fishery is identified as full-time jobs.

Socio-economic returns from the fishery are defined in this model as the sum of resource rent and inframarginal rents, where the latter relate to producer surplus. Producer surplus is derived from the existence of heterogeneous fishers and captures the extra rents that fishers who are more efficient than average obtain (for a discussion, see Copes, 1972). Resource rent is defined as the net surplus that is achieved after the remuneration of labor and capital at the rate of other Spanish economic activities (see e.g., Copes, 1972). Hence, the resource rent is identified by deducting the opportunity cost of labor and capital to estimate the

\footnotetext{
${ }^{7}$ Fuel-tax exemptions are not an exclusive exemption for the fishing sector. In Spain, the aviation, navigation and railway transport sectors are also subject to that exemption. In the case of agriculture, a reduction instead of an exemption of the fuel tax prevails (Spain, Law 38/1992 of 28 December 1992).
}

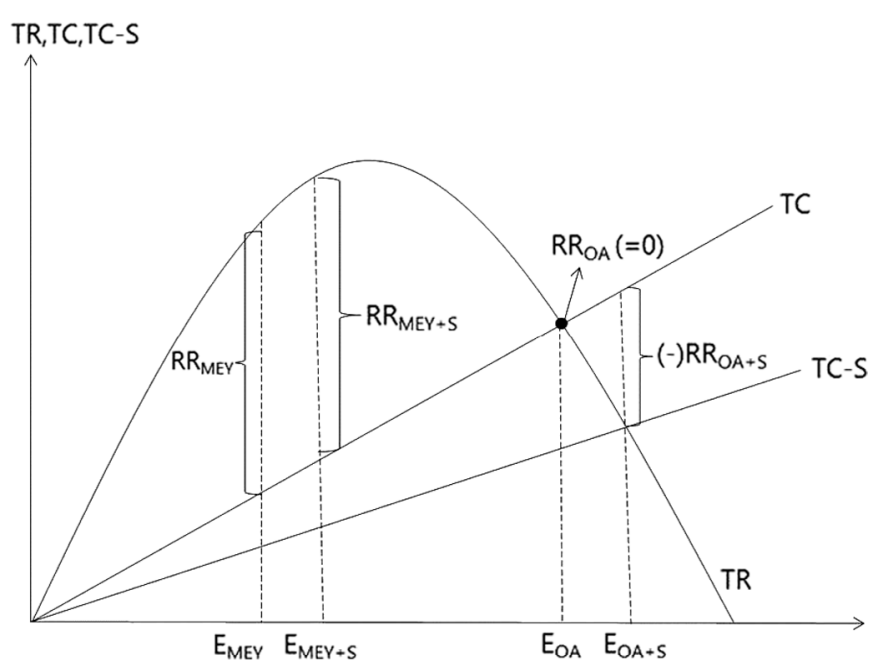

Fig. 1. Bio-economic model of fisheries with and without subsidies.

benefit for society of applying capital and labor in the fishery, as compared to alternative businesses (Nielsen et al., 2012). Consumer surplus is not considered, since it is assumed that the production of this specific fishery is marginal to the market and so any change in it would not affect that welfare indicator (see e.g., Turvey, 1964).

Figure 1 describes the model. TR represents total revenue for the fleet and includes income from landings assuming constant prices. The $T R$ curve corresponds to a long-run biological equilibrium and thus follows the sustainable yield at different levels of effort. $T C$ refers to total costs and includes all variable and fixed costs, with labor and capital as opportunity costs. TC-S represents the same cost curve, but reduced by the size of the subsidies. At the x-axis, $E$ is fishing effort measured as days at sea. Under open access $(O A)$, it can be expected from the theory (see e.g., Gordon, 1954) that fishing effort is situated at the point where $T R$ equals $T C$, at $E_{O A}$, where the resource rent is dissipated $\left(R R_{O A}\right)$. In this situation, because of the existence of subsidies $(S)$, the effort is expected to reach the point where $T R$ equals $T C-S$, at $E_{O A+S}$, where the resource rent is also dissipated $\left(R R_{O A+S}=0\right)$ and where society faces a welfare loss of having a fishery at the size of the subsidy. The fishing effort chosen by the industry is determined by costs and revenues, which at the same time are shaped by cost-reducing and revenue-enhancing subsidies.

Under optimal fisheries management, defined as MEY, the fishery is in equilibrium at the point where the distance between $T R$ and $T C$ is the maximum, at effort level $E_{M E Y}$ and resource rent $R R_{M E Y}$. Including subsidies, the level of effort associated with the optimum is also determined by the level of subsidies in the fishery, even though these are not included in the calculation of resource rent. The fishery reaches the optimum where the slopes of the $T C-S$ curve and the $T R$ curve are equal. At that level of effort, resource rent corresponds to the difference between $T R$ and $T C, R R_{M E Y+S}$.

Mathematically, the model is characterized as follows. Current resource rent is represented as:

$$
R R_{0}=\sum_{i=1}^{n} L_{i}^{0} p_{i}-V C_{0}-F C_{0}
$$




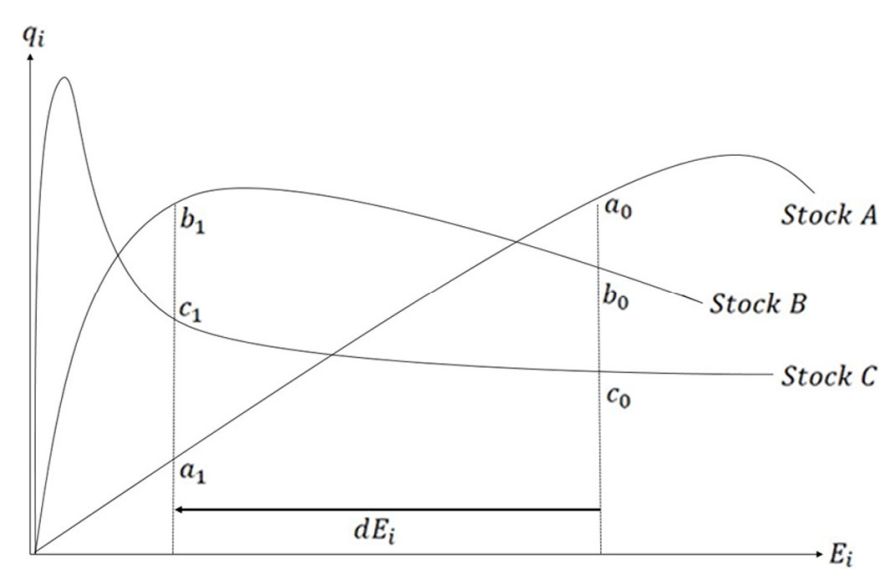

Fig. 2. Sustainable yield functions in multispecies fisheries at current and future effort.

where $R R_{0}$ is economic returns in the current situation, $L_{i}^{0}$ is current catches for stock $i, p_{i}$ refers to price of fish for stock $i$, which is assumed to be constant over time, $V C$ is the variable costs, including opportunity cost of labor, and $F C$ is fixed costs, including opportunity cost of capital.

In a situation of open access, fishing effort will be situated at the point where total revenue equals total cost. At this effort level, any resource rent would be dissipated. MEY situates the social optimum at the point where marginal revenue equals marginal cost. The estimation of the maximum economic return requires the identification of revenues and costs in the industry. Total revenue $(T R)$ is calculated as:

$$
T R=\sum_{i=1}^{n} L_{i} p_{i}
$$

It is assumed that $L_{i}=q_{i}$, where $q_{i}$ is the maximum fish amount that can be caught annually on a biologically sustainable basis from a particular stock. It is an assumption of the model that fish stocks are currently in steady state, so the level of effort associated with the current landings is sustainable $\left(G\left(P_{i}\right)=q_{i}\right)$ which means that the fish population is stable, and the rate of fishing is exactly compensated for by the intrinsic growth rate. It is also assumed that fishing opportunities are entirely exploited. The Northwest Spanish fleet operates a multispecies fishery, where different fish stocks exist. The model measures the effect on the economic return of a simultaneous and equal change in the effort level in all stocks involved, as described in Figure 2, which compares the current situation 0 with a future situation 1 at a lower effort level. Therefore, it is assumed that the relative fishing effort on every stock is constant, i.e., that $E_{i, 1} / E_{1}=E_{i, 0} / E_{0}$ and that the share of the stocks fished by the fleet analyzed is also constant. Fish stocks that are not explicitly included in the analysis are assumed to develop exactly like those included. Furthermore, this article does not distinguish between different types of vessels within the fleet analyzed, i.e., small or large vessels, but takes the representative average vessel as the subject of analysis. As a consequence, it implies that changes in effort affect every vessel group proportionally.

The production function at the sustainable level is expressed as $q_{i}=f\left(P_{i}\left(E_{i}\right)\right)$ where $P$ is the fish population

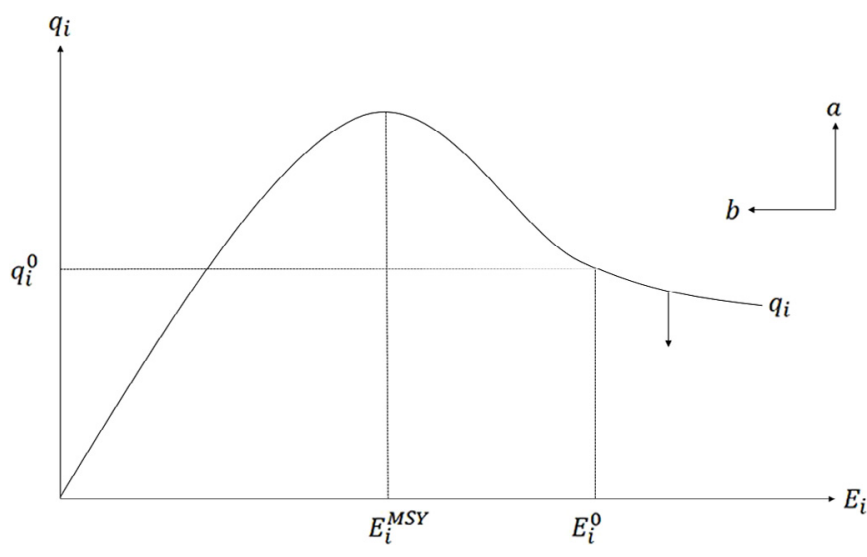

Fig. 3. The Gompertz-Fox sustainable yield function for each stock.

level and $E$ the fishing effort of the fleet for stock $i$. Considering that the current situation is steady state, $P=0$, annual natural growth, $G(P)$, equals catches $q$ for every stock, $q_{i}=G\left(P_{i}\right)$. This model assumes that the natural growth function develops as a Gompertz-Fox function, $G\left(P_{i}\right)=-r P_{i} \ln \left(P_{i} / K\right)$, where $r$ and $K$ are the parameters of the growth function. Combining the Schaefer harvest function, $q=y E P$ (where $y$ is the catchability coefficient), with the previous equations gives:

$$
q_{i}=a E_{i} \exp ^{-\left(b E_{i}\right)}
$$

where $a$ is equal to $y K$ and $b$ is equal to $y / r$. With increasing effort, the sustainable catch level increases until it reaches a peak at the maximum sustainable yield. Further effort decreases catches, approaching zero when effort tends to infinity. Positive changes in $y$, the catchability coefficient, make less effort necessary for unchanged sustainable yield. It is considered that if the effort is above the effort level corresponding to MSY, the stock biomass is below the biomass corresponding to the MSY. For each of the stocks analyzed, the parameters $a$ and $b$ are calibrated, identified by experiments where the peak in the sustainable yield function is at $E_{M S Y}$, using the method illustrated in Figure 3. As indicated by the arrows, $b$ moves the peak (MSY) horizontally, whereas $a$ shifts the peak vertically. When $b$ increases, the peak moves to the left until it peaks in MSY. On the other hand, when $a$ increases the curve is moved upward until it intersects the current $q_{i}$ point. The downward-pointing arrow indicates that if the assumption of steady state is not maintained, the identified curve overestimates the sustained yield. The estimated values for the parameters $a$ and $b$ for each of the stocks included in the model can be found in Table 2 .

The effort level at MSY is calculated from the relationship between $P$ and $E$ :

$$
P_{i, 1} / P_{i, 0}=\beta\left(E_{i, 1} / E_{i, 0}\right)^{-z}
$$

where $\beta$ is a constant and $z$ is the elasticity effort-biomass, which indicates how a change in fishing effort affects the stock population. In the case where $\beta$ and $z$ are normalized to 1 , percentage changes in effort will affect the fishing population in the same percentage, but with the opposite sign. To calculate the effort level that corresponds to $\operatorname{MSY}\left(E_{i, 1}\right)$, data on current and 
Table 2. Calibrated parameter values of the sustainable yield function for each stock.

\begin{tabular}{lcl}
\hline & Parameter $a$ & Parameter $b$ \\
\hline Hake VIIIc IXa & 44 & 0.0023 \\
Tuna North Atlantic & 40 & 0.0016 \\
Horse mackerel NE Atlantic & 62 & 0.0010 \\
Sardine VIIIc-IXa & 47 & 0.0018 \\
Anchovy VIII & 38 & 0.0012 \\
Atlantic mackerel NE Atlantic & 179 & 0.0012 \\
\hline
\end{tabular}

estimated biomass at $\operatorname{MSY}\left(P_{i, 0}\right.$ and $P_{i, 1}$, respectively) and current effort level $\left(E_{i, 0}\right)$ are introduced into the previous equation.

The estimation of total cost assuming constant input prices is:

$$
T C=Q\left(V C_{0}+F C_{0}\right) \quad \text { where } \quad Q=\alpha\left(E_{1} / E_{0}\right)^{(1+v)}
$$

where $V C$ refers to variable costs, those dependent on fishing activity, $F C$ stands for fixed costs from a short-term perspective, such as capital costs or depreciation, but which in this long-term model are also considered as variable and include opportunity costs of labor and capital, $Q$ describes how costs change when the level of effort is modified, $\alpha$ is a positive constant, normalized to 1 , and $v$ accounts for the differences in efficiency between vessels, which originates from inframarginal rents and may be a consequence of uneven skills and knowledge among fishers (see e.g., Copes, 1972). Following Nielsen et al. (2012), $v$ is considered to be equal to 0.33 .

As the resource rent is a welfare indicator, subsidies are not directly included in its calculation because of their characterization as transfers between the government and the fishing industry. However, they do influence activity and investment in the fishery (see e.g., Grimsrud et al., 2015). Therefore, identifying fishing effort associated with the optimum for each of the scenarios, resource rent plus subsidies is maximized. Once effort corresponding to this optimum is found, the maximum resource rent is identified for that level of fishing effort.Those subsidies that are going to reduce costs for the fleet, and so influence their behavior, have to be included in the $T C$ function for the estimation of optimum fishing effort:

$$
T C_{S}=Q\left(V C_{0}+F C_{0}-S\right) \text { where } Q=\alpha\left(E_{1} / E_{0}\right)^{(1+v)}
$$

where $S$ refers to cost-reducing subsidies. As revenueenhancing subsidies are not considered in this model, these comprise all public funding allocated to the fishery of study.

The maximum economic return is then equal to $R R_{M E Y}=\operatorname{Max}_{E_{1}} R R_{0}$, as it is the result of maximizing the difference between revenues and costs, resulting in an optimum level of effort. Combining equations (2)-(5) and rearranging gives:

$$
\begin{array}{r}
R R_{M E Y}=\operatorname{Max}_{E_{1}}\left\{\sum_{i=1}^{n}\left(a P_{i, 0} E_{i, 0} / P_{i, 1} \exp ^{-\left(b P_{i, 0} E_{i, 0} / P_{i, 1}\right)}\right) p_{i}\right. \\
\left.-\left(E_{1} / E_{0}\right)^{(1+v)}\left(V C_{0}+F C_{0}\right)\right\} \text { subject to } q_{i}=G\left(P_{i}\right)
\end{array}
$$

\begin{tabular}{|c|c|c|}
\hline Scenario & Fisheries management & Subsidies \\
\hline I & Current & $\begin{array}{l}\text { Current: fuel-tax exemptions, } \\
\text { grants, general services }\end{array}$ \\
\hline II & Optimal (MEY) & $\begin{array}{l}\text { Current: fuel-tax exemptions, } \\
\text { grants, general services }\end{array}$ \\
\hline III & Optimal (MEY) & $\begin{array}{l}\text { General services (removing } \\
\text { fuel tax exemption subsidies } \\
\text { and grants) }\end{array}$ \\
\hline IV & Optimal (MEY) & No subsidies \\
\hline V & Optimal (MEY) & Double current subsidies \\
\hline
\end{tabular}

Table 3. Scenarios I-V and their different subsidy levels.

However, this resource rent is limited by the optimum effort level that results from maximization of $R R$ plus subsidies, $E_{M E Y+S}$. This is because fishing activity is also influenced by lower costs that derive from the existence of subsidies.

Combining equations (2)-(4), and (6) and rearranging gives:

$R R_{M E Y+S}=\operatorname{Max}_{E_{1}}\left\{\sum_{i=1}^{n}\left(a P_{i, 0} E_{i, 0} / P_{i, 1} \exp ^{-\left(b P_{i, 0} E_{i, 0} / P_{i, 1}\right)}\right) p_{i}\right.$
$\left.-\left(E_{1} / E_{0}\right)^{(1+v)}\left(V C_{0}+F C_{0}-S\right)\right\}$ subject to $q_{i}=G\left(P_{i}\right)$

Finally, $E_{M E Y+S}$ resulting from equation (8) is introduced into equation (7) as the set optimum effort level to find the optimum resource rent in the fishery:

$$
\begin{aligned}
R R_{M E Y}= & \operatorname{Max}_{E_{M E Y+S}}\left\{\sum_{i=1}^{n}\left(a E_{i, M E Y+S} \exp ^{-\left(b E_{i, M E Y+S}\right)}\right) p_{i}\right. \\
& \left.-\left(E_{M E Y+S} / E_{0}\right)^{(1+v)}\left(V C_{0}+F C_{0}\right)\right\}
\end{aligned}
$$

This study analyzes three types of subsidies: fuel tax exemption; grants for construction and modernization of vessels; and those related to general services, such as specific infrastructure, management, and research. Following OECD (2000), all of these are treated as cost-reducing subsidies and so affect the cost curve of the industry (see e.g., UNEP, 2004, for further discussion).

The model is run for five different scenarios: the current situation and four others that correspond to a situation of optimal management with different subsidy levels, as shown in Table 3.

The first, scenario I, corresponds to the current situation without changes in either management or subsidy level. The other scenarios assume optimal management, defined as MEY, and changes are introduced in terms of size and typology of the subsidies. Scenario II estimates the situation in MEY without changing the subsidy levels. The other scenarios, III, IV, and V, introduce different changes in the size and typology of the subsidies, also under an optimum management scheme. Scenario III removes fuel-tax exemptions and grants and is justified by the current debate on the definition of good or bad subsidies. For example, public funding for research on fisheries may be appropriate as a welfare-increasing policy 
Table 4. Physical and economic data, 2014 (Subsidies 2013).

\begin{tabular}{ll}
\hline Physical data & \\
\hline No. vessels & 4553 \\
Average effort (days at sea) & 175 \\
Total effort of the fleet (days at sea) & 796775 \\
No. workers (full-time jobs) & 10169 \\
Account data (€million) & \\
Value of landings & 319 \\
Fuel costs & 54.7 \\
Other running costs & 64.7 \\
Labor costs & 128.6 \\
Opportunity cost of labor & 167 \\
Gross cash flow & 32.6 \\
Opportunity cost of capital & 13.3 \\
Depreciation & 11.6 \\
Net profit & 7.7 \\
Invested capital & 455.3 \\
Subsidies (€ million) & 12.5 \\
Fuel tax exemption subsidies & 10.1 \\
Grants & 0.1 \\
General services & 2.3 \\
\hline
\end{tabular}

(Squires et al., 2014). Scenario IV eliminates all of the subsidies included in the model. Scenario V elaborates on an increase in all subsidies that double the current level, as opposed to the previous scenarios that only consider cuts in subsidies. This scenario is included to ensure consistency of the model and is not a realistic policy option today, but represents a sensitivity analysis.

\section{Data}

The dataset includes biological, physical, and economic data from the selected fishery. Physical and economic data, except that related to subsidies, are from 2014 and are taken from official statistics of Encuesta Económica de la Pesca (MAGRAMA, 2014a). The physical and economic data are shown in Table 4.

The opportunity cost of labor is the average annual salary for a Spanish worker with a basic education in 2014 (INE, 2015). The opportunity cost of capital is calculated as invested capital times a real interest rate of 2.92\% (STECF, 2016b). Invested capital is estimated with information obtained from a Spanish shipyard on the sales value of a new vessel with the characteristics of the average vessel for the area of study, and equals $€ 200000$. This number is reduced to half, following the methodology suggested by Franquesa et al. (2001), in order to estimate the current value of the individual vessel.

Data on subsidies are taken from OECD $(2016)^{8}$ and are from 2013, the latest available at the time of writing. Due to the lack of region-specific data, the size of the fishing subsidies allocated to the area of study is estimated. It is assumed that the

\footnotetext{
${ }^{4}$ The OECD database gathered information as Government Financial Transfers (GFT) from official data sources, using the Fisheries database questionnaire. Recently, the OECD has substituted the GFT methodology by the Fisheries Support estimate, which includes a slightly different classification of subsidies.
}

fuel-tax exemption subsidy is proportionally related to the fuel costs of the fishing firms and hence it represents a fixed percentage of these. Therefore the relationship between the national fuel costs and regional fuel costs must be the same as between the national and regional fuel-tax exemption subsidy. It is shown that fuel costs for the fleet of study amount to $15.3 \%$ of the total Spanish fleet fuel costs. Accordingly, the regional subsidy will also represent $15.3 \%$ of the national subsidy from OECD statistics. For all other subsidies where data are only available at national level, the same share is applied, in order to determine the total subsidy level for the fleet studied.

Biological data for estimating the long-run sustainable yield cover the six main fish stocks for the Northwest Spanish fleet (following the International Council for the Exploration of the Sea (ICES) classification of fishing areas): hake in areas VIIIc and IXa, North Atlantic tuna, Northeast Atlantic horse mackerel, sardine in areas VIIIc and IXa, anchovy in area VIII, and Northeast-Atlantic Atlantic mackerel. Also included are data on spawning stock biomass in the current situation and in the point corresponding to MSY for hake, horse mackerel, sardine, and anchovy, and data from 2014 for Atlantic mackerel. Tuna information (for 2013) is taken from a report by the International Commission for the Conservation of the Atlantic Tunas (ICCAT, 2013) (ICES, 2014, 2015a, 2015b; ICCAT, 2013).

Information on catches for the six stocks analyzed is taken from official statistical sources in each of the four autonomous communities in the area of study and then combined (Dirección General Pesca Marítima, 2014; ICANE, 2014; NASDAQ, 2014; Xunta de Galicia, 2014). Because of the lack of official information on landings of Atlantic mackerel for the Basque fleet, the value is estimated from the allocation of quotas for that species for 2014 (Spain, Order AAA/417/2014, of 17 March, 2014), assuming that actual landings occurred in the same proportion as the specified quotas. The ex-vessel price is set as the average of the other three autonomous communities for which there are official statistics (Galicia, Asturias, and Cantabria). The Northwest Spanish fishing fleet fishes on more than one stock of the same fish species, so the catches corresponding specifically to the six chosen stocks are calculated by comparing information on catches by country for all stocks (ICES, 2014, 2015a, b).

The biological data are presented in Table 5.

\section{Results and discussion}

The results for the five scenarios in terms of resource rent, including inframarginal rent, fishing effort, employment, and public funds allocated to the fishery, are shown in Table 6.

Scenario I, the baseline, represents the current situation of the Northwest Spanish fishing fleet. The current economic performance of the vessels analyzed, in terms of resource rent and producer surplus, is positive and amounts to $€ 7.7$ million.

By optimizing the resource rents, including the inframarginal rent, from the fishery to achieve MEY, the results show that resource rents including the inframarginal rent significantly increase. This is true for all of scenarios II-V, ranging from no subsidies in scenario IV (where the result is $€ 164.6$ million) to doubled subsidies in scenario $\mathrm{V}(€ 161.9$ million). The estimated economic outcome is about $50 \%$ of the 
Table 5. Biological data.

\begin{tabular}{|c|c|c|c|c|c|c|c|}
\hline & & $\begin{array}{l}\text { Hake } \\
\text { VIII-IXa }\end{array}$ & $\begin{array}{l}\text { Tuna N } \\
\text { Atlantic }\end{array}$ & $\begin{array}{l}\text { Horse mackerel } \\
\text { NE Atlantic }\end{array}$ & $\begin{array}{l}\text { Sardine } \\
\text { VIIIc-IXa }\end{array}$ & $\begin{array}{l}\text { Anchovy } \\
\text { VIII }\end{array}$ & $\begin{array}{l}\text { Atlantic mackerel } \\
\text { NE Atlantic }\end{array}$ \\
\hline $\mathrm{SSB}_{\text {current }}$ (Tons) & & 18836 & 41600 & 838100 & 123241 & 147485 & 4605000 \\
\hline \multirow[t]{2}{*}{ Regional catches } & Tons & 5651 & 9232 & 22944 & 8915 & 11761 & 57161 \\
\hline & Million $€$ & 20.9 & 31.96 & 16.8 & 7.97 & 20.6 & 43.1 \\
\hline
\end{tabular}

Table 6. Results for scenario I-V in terms of resource rent, effort, employment, and allocated public funding.

\begin{tabular}{llllrl}
\hline Scenario & $\begin{array}{l}\text { Resource rent } \\
(€ \text { million })\end{array}$ & Change in effort $\%$ & No. vessels & $\begin{array}{l}\text { No. full-time } \\
\text { workers }\end{array}$ & $\begin{array}{l}\text { Public funds allocated } \\
\text { to the fishery }(€ \text { million })\end{array}$ \\
\hline I & 7.7 & 0 & 4553 & 10169 & 12.5 \\
II & 160.9 & -58.2 & 1427 & 3182 & 12.5 \\
III & 162.1 & -59 & 1391 & 3102 & 2.3 \\
IV & 164.6 & -59.1 & 1386 & 3091 & 0 \\
V & 161.9 & -57.2 & 1473 & 3285 & 25 \\
\hline
\end{tabular}

catch value (compare with e.g., Asche et al. (2009) who reports $60-73 \%$ for Norwegian cod fisheries). The difference between the scenarios is in the amount of public funds allocated to the fishery. Scenario III eliminates all subsidies except general services, amounting to $€ 2.3$ million, while no subsidies are left in scenario IV. From the results, it can be seen that there is no substantial difference in terms of social welfare or fishing activity from including or excluding subsidies to general services from the fishery. Thus, if general services are expected to generate public benefits that are not explicitly incorporated in the modeling framework, they could be maintained without substantially altering the performance of the sector, and indeed general services could be valuable to improve the long-run management of the sector.

The fuel-tax exemption is the largest of the subsidies. It is not unique for the fishing sector, which raises questions about whether the exemption should be compared to sectors with full taxation or not. In addition, the data used may contain an element of uncertainty. Therefore, a sensitivity analysis for different sizes of the subsidy is performed. No significant changes in the results of the model are apparent from selecting a fuel-tax exemption subsidy that is half, double, or $200 \%$ greater than that finally considered.

The reduction in effort is significant in all cases: almost $60 \%$ of current fishing activity, which implies that approximately $70 \%$ of the active vessels currently operating must exit the fishery. In terms of employment, this translates into approximately $70 \%$ fewer full-time jobs, or around 7000 people directly losing their source of livelihood. For example, in the case of Galicia, the region that accounts for $90 \%$ of the fleet for the area of study, a reduction of $70 \%$ in the number of vessels from the domestic fleet means that around 6500 fishers would lose their job. This represents $0.7 \%$ of the total active workforce in Galicia. The general unemployment rate in this region is currently $17.4 \%$ of the active population (IGE, 2017) and therefore it any further decline in employment can be expected to have a negative social impact, especially in coastal communities, where the importance of the fishing sector in terms of employment is higher (see e.g., Natale et al. (2013), who estimates the high employment dependency of fisheries in local communities in Galicia). A reduction of more than half the size of the fishing fleet might also have a negative impact on the fish processing sector in the short and medium term, due to the reduction in fish harvesting, but likely a positive impact in the long-term, once the fish stocks have recovered. In Galicia, the fish processing industry employs more than 10000 workers, which represents $7.6 \%$ of the manufacturing industrial workforce in the region and accounts for around $1 \%$ of the gross domestic product (GDP) of Galicia (IGE, 2015).

The estimated optimal equilibrium requires the reallocation of labor and capital to alternative occupations. In the long run, fishers can be expected to find a new occupation and invested capital can be recovered and placed in other businesses. In the short term, however, transition to an optimal management situation is likely to involve losses for the fishing sector. Many fishers would have to exit the fishery and find another occupation, and vessel capital would have to be removed. The generally low mobility of fishers and nonmalleability of capital in the fishery may prolong and determine the adjustment path to the social optimum, and this should be considered when planning an effort-reducing management scheme. Clark et al. (1979) oppose extreme management policies of stock conservation because of this. In this context, a slow adjustment path is also proposed by Grévobal and Munro (1999), who suggest partial elimination of excess vessels and full employment of the remaining capacity, without allowing new investment. Over time, the capital depreciation would steadily reduce the fleet capacity.

According to Weber (1994), a managed reduction in effort should also consider the character of the fleet involved. Small- 
scale fisheries are the dominant type of exploitation in this study, since the artisanal fleet represents $90 \%$ of the total number of vessels, around 4000 vessels, representing in Galicia $65 \%$ of the fish harvesting employment and $26 \%$ in terms of landing revenue (Xunta de Galicia, 2015). Small-scale fisheries support higher employment levels for a given level of production than industrial fisheries, and therefore in the case that preservation of employment is relevant, reduction in effort may be directed towards the industrial fleet. In any case, the high dependence of fisheries in terms of employment in most of the coastal Northwest Spanish area suggests that negative socioeconomic consequences are likely to follow from a reduction in fishing activity. According to Bruvoll et al. (2011), compensation measures for those leaving the fishery are necessary to ensure the sustainability of the community and also to increase the political acceptance of a new management scheme. Examples of compensation measures are suggested by Bhat and Bhatta (2006), such as job creation programs, employment training, or indirect compensation. Heymans et al. (2011) propose gradual elimination of subsidies. These funds could be used to improve conservation of the stocks (Sumaila et al., 2010). The compensation to those leaving the fishery could also be funded through the released funds from the reduction in subsidies, as suggested by Carvalho et al. (2011). It is suggested that this income support should be temporary and not attached to effort or catch level, but designed as lumpsum payments to avoid potential adverse effects (see e.g., Arnason, 1998). Once the stock recovers and the fishing fleet is restructured, these funds should be gradually removed.

Although the Northwest Spanish fleet contains both largeand small-scale vessels, they are treated as a homogenous group in our empirical model. Thus, a reduction in the fleet is assumed to be equally distributed between large and small vessels, which is a strong assumption. Small-scale vessels use passive fishing techniques (e.g., gill-net) and are thus less dependent on fuel than larger vessels using active fishing techniques (e.g., trawl). Reducing the fuel subsidy will thus have a smaller effect on the cost structure for the small-scale fleet, causing the negative short-term effects of reduced subsidies to be smaller for this fleet. On the other hand, smallscale vessels are estimated to have lower initial profitability (STECF, 2015) and therefore are more sensitive to increased costs. Thus, the relative importance of reduced fuel subsidies for small- and large scale vessels is an empirical question that is not possible to analyze in the model framework used here. Further, the response to the introduction of economically efficient management system (e.g., ITQs) could differ between the fleet segments. If small-scale vessels are less profitable than larger vessels, the expected development is that the smallscale fleet will be reduced more. This has caused many ITQ systems to have special rules to protect the small-scale fleet. Waldo and Paulrud (2016) analyze fuel taxes and coastal fleet policies for Sweden and show that the small-scale fleet would be heavily reduced on introducing ITQs, while reducing fuel subsidies in this setting would cause the fleet to increase again to some extent. Further, allocating quotas for small-scale fisheries is a way to protect this fleet, but the interaction between this policy measure and the reduction of fuel subsidies is complex, e.g., parts of the quotas allocated to small-scale fisheries may be unutilized due to high fuel costs.

\section{Conclusions}

If fisheries were managed efficiently to achieve MEY, there could be substantial increases in social welfare from higher resource rents, including inframarginal rents, in the Northwest Spanish fishing fleet. To reach the optimum, reductions in fishing effort are necessary through reductions in labor and capital. A reduction in subsidies under optimal management leads to higher resource rents and lower effort levels. In all scenarios, the impact is small, however. Improvements in social welfare must be mainly attributed to the improvement in management. The high dependency of many communities in the Northwest Spanish region on fishing employment, and the low mobility of labor and imperfect malleability of capital in fisheries, suggest that the short-term impacts on the area from reducing effort are likely to be important. For this reason, compensation measures in the short term can be given to those leaving the fishery and to communities, to encourage the development of employment alternatives. The elimination of subsidies is a possible way of increasing social welfare and releasing public funds that may be available to fund compensation programs. The existence of subsidies under optimal management makes little sense if justified in terms of supporting fishers' income. The results highlight the importance of fisheries management when discussing reductions in subsidy levels.

\section{References}

Arnason R. 1998. Fisheries subsidies, overcapitalization and economic losses, in: Workshop, Presented at the Overcapacity, Overcapitalization and Subsidies in European Fisheries, Center for the Economics and Management of Aquatic Resources of the University of Portsmouth, Portsmouth, UK.

Arnason R. 2000. Costs of Fisheries Management: Theoretical and Practical Implications, IIFET Proceedings.

Asche F, Bjørndal T, Gordon DV. 2009. Resource rent in individual quota fishery. Land Econ 85: 280-292.

Bhat MG, Bhatta R. 2006. Regional economic impacts of limited entry fishery management: an application of dynamic input-output model. Environ Dev Econ 11: 709-728.

Brady M, Waldo S. 2009. Fixing problems in fisheries - integrating ITQs, CBM and MPAs in management. Mar Policy 33: 258-263.

Bruvoll A, Skjelvik JM, Vennemo H. 2011. Reforming environmentally harmful subsidies: how to counteract distributional impacts, Nordic Council of Ministers, Copenhagen, Denmark.

Carvalho N, Rege S, Fortuna M, Isidro E, Edwards-Jones G. 2011. Estimating the impacts of eliminating fisheries subsidies on the small island economy of the Azores. Ecol Econ 70: 1822-1830.

Clark CW, Clarke FH, Munro GR. 1979. The optimal exploitation of renewable resource stocks: problems of irreversible investment. Econometrica 47: 25-47.

Copes P. 1972. Factor rents, sole ownership and the optimum level of fisheries exploitation. Manch Sch Econ Soc Stud 40: 146-163.

Cordón Lagares E, García Ordaz F. 2015. Factors influencing the decision to leave a fishery and the effects of fishery subsidies: the case of the Spanish purse seine fishery. Ocean Coast Manag 116: 248-256.

2014. Dirección General de Pesca Marítima Asturias, Estadísticas Capturas de especies [WWW Document]. URL http://tematico. asturias.es/dgpesca/din/estalonj.php? cofra=99\&year $=2014$ (accessed on: 2016/02/01). 
European Commission. 2013. Regulation (EU) on the Common Fisheries Policy, amending Council Regulations (EC) No 1954/ 2003 and (EC) No 1224/2009 and repealing Council Regulations (EC) No 2371/2002 and (EC) No 639/2004 and Council Decision 2004/585/EC, Official Journal of the European Union.

European Commission. 2014. Facts and figures on the Common Fisheries Policy.

European Commission. 2015. The eighth annual report on implementation of the European fisheries fund (2014), COM (2015)662 final.

FAO. 2014. The State of World Fisheries and Aquaculture 2014, Food and Agricultural Organization of the United Nations, Rome.

Franquesa R, Malouli IM, Alarcón JA. 2001. Feasibility assessment for a database in socioeconomic indicators for Mediterranean fisheries (No. 71), Studies and Reviews, General Fisheries Commission for the Mediterranean, Food and Agricultural Organization of the United Nations, Rome.

Freire J, García AA. 2000. Socioeconomic and biological causes of management failures in European artisanal fisheries: the case of Galicia (NW Spain). Mar Policy 24: 375-384.

Gordon HS. 1954. The economic theory of a common-property resource: the fishery. J Polit Econ 62: 124-142.

Grévobal D, Munro GR. 1999. Overcapitalization and excess capacity in world fisheries: underlying economics and methods of control, in: D. Grévobal (Ed.), Managing Fishing Capacity, Selected Papers on Underlying Concepts and Issues, FAO Fisheries Technical Paper 386, 75-1999, Rome.

Grimsrud K, Lindholt L, Greaker M. 2015. Resource rent in Norwegian fisheries - trends and policies ( Discussion papers No. 827), Statistics Norway, Research Department.

Hardin G. 1968. The tragedy of the commons. Sci New Ser 162: 12431248.

Heymans JJ, Mackinson S, Sumaila UR, Dyck AJ, Little A. 2011. The impact of subsidies on the ecological sustainability and future profits from North Sea fisheries. PLoS ONE 6: e20239.

Holland D, Gudmundsson E, Gates J. 1999. Do fishing vessel buyback program work: a survey of the evidence. Mar Policy 23: 47-69.

ICANE. 2014. Estadísticas pesca subastada Cantabria [WWW Document]. URL http://www.icane.es/data/results\#content (accessed on: 2016/01/02).

ICCAT. 2013. Report of the 2013 ICCAT North and South Atlantic albacore stock assessment meeting, Sukarrieta, Spain.

ICES. 2014. Report of the working group on Southern Horse Mackerel, Anchovy and Sardine (WGHANSA), Copenhagen, Denmark.

ICES. 2015a. Report of the ICES Advisory Committee 2015 (No. Book 7), ICES advice.

ICES. 2015b. Report of the ICES Advisory Committee 2015 (No. Book 9), ICES advice.

Instituto Gallego de Estadística (IGE). 2015. Analise do sector da pesca. Xunta de Galicia, Santiago de Compostela.

Instituto Gallego de Estadistica (IGE). 2017. Enquisa do poboacion activa (EPA) [WWW Document]. URL http://www.ige.eu (accessed on: 2017/10/06).

INE. 2015. Decil de salarios del empleo principal, Encuesta de Población Activa (EPA). Año2014, 2015 [WWW Document]. URL http://www.ine.es/prensa/np939.pdf (accessed on: 2016/03/ 15).

Joint statement regarding fisheries subsidies, 2016, by several WTO member countries. September 14, 2016. Our ocean conference, Washington. URL https://ustr.gov/sites/default/files/0914 2016_STATEMENT_joint_statement_fisheries_partners_FINAL. pdf
Losada A. 2000. La política del mar. Políticas públicas y autonomía, El caso de la pesca gallega. Ed Istmo Col Fundam, p. 173.

MAGRAMA. 2014a. Estadísticas pesqueras: Encuesta Económica de Pesca Marítima, Minist. Aliment. Agric. Medio Ambiente Gob. Esp.

MAGRAMA. 2014b. Informe anual de la actividad de la flota pesquera española, Minist. Aliment. Agric. Medio Ambiente Gob. Esp.

Merayo E, Nielsen R, Hoff A, Nielsen M. 2017. Are individual transferable quotas an adequate solution to overfishing and overcapacity? evidence from Danish fisheries. Mar Policy, forthcoming.

Minnegal M, Dwyer PD. 2008. Mixed messages: buying back Australia's fishing industry. Mar Policy 32: 1063-1071.

NASDAQ. 2014. Pesca de bajura subastada por puertos y principales especies en País Vasco [WWW Document]. URL http://www. nasdap.net/estadisticas/Pesca_puerto_14.htm (accessed on 2016/ $01 / 02)$

Natale F, Carvalho N, Harrop M, Guillen J, Frangoudes K. 2013. Contribution of fisheries to employment in EU coastal areas. Mar Policy 42: 245-252.

Nielsen M, Flaaten O, Waldo S. 2012. Management of and economic returns from selected fisheries in the Nordic countries. Mar Resour Econ 27: 65-88.

Nielsen M, Andersen P, Ravensbeck L, Laugesen F, Kristófersson D, Ellefsen H. 2017. Fisheries management and the value chain: the Northeast Atlantic pelagic fisheries case. Fish Res 186: 36-47.

OECD. 2000. Transition to responsible fisheries: economic and policy implications, OECD Publishing, Paris.

OECD. 2016. Fisheries: government financial transfers, OECD Agric. Stat. Database.

Pascoe S, Coglan L, Punt AE, Dichmont CM. 2012. Impacts of vessel capacity reduction programmes on efficiency in fisheries: the case of Australia's multispecies Northern prawn fishery. J Agric Econ 63: 425-443.

STECF. 2014. Scientific, Technical and Economic Committee for Fisheries (STECF). The Economic Performance Report on the EU Fish Processing (STECF-14-21), Publications Office of the European Union, Luxembourg.

STECF. 2015. Scientific, Technical and Economic Committee for Fisheries (STECF). The 2015 Annual Economic Report on the EU Fishing Fleet (STECF-15-07), Publications Office of the European Union, Luxembourg.

STECF. 2016a. Scientific, Technical and Economic Committee for Fisheries (STECF). Monitoring the performance of the Common Fisheries Policy (STECF-16-03), Publications Office of the European Union, Luxembourg.

STECF. 2016b. Scientific, Technical and Economic Committee for Fisheries (STECF). The 2016 Annual Economic Report on the EU Fishing Fleet (STECF 16-11), Publications Office of the European Union, Luxembourg.

Spain, Head of State. Law 38/1992 of Special Taxes, of 28 December. Official State Gazette (BOE), nr. 312, of 29 December 1992, pp. 44305-44331.

Spain, Ministry of Agriculture, Fisheries and Food. Royal Decree 560/1995, of 7 April 1995, establishing minimum sizes for some fishing species. Official State Gazette (BOE) nr. 84, of 8 April 1995, pp. 10552-10554.

Spain, Ministry of Agriculture, Food and Environment. Order AAA/ 417/2014, of 17 March 2014, modifying Order AAA/1307/2013 of 1 July, establishes a management plan for the fishing fleet operating in national waters in the Cantabrian NW. Official State Gazette (BOE), nr. 66, of 18 March 2014, pp. 23690-23698. 
Spain, Ministry of Agriculture, Food and Environment. Order AAA/ 2534/2015, of 17 November 2015, establishing a management plan for the fishing fleet operating in national waters in the Cantabrian NW. Official State Gazette (BOE), nr. 286, of 30 November 2015, pp. 113184-113217.

Squires D, Clarke R, Chan V. 2014. Subsidies, public goods, and external benefits in fisheries. Mar Policy 45: 222-227.

Sumaila UR, Khan AS, Dyck AJ, Watson R, Munro GR, Tydemers P, Pauly D. 2010. A bottom-up re-estimation of global fisheries subsidies. J Bioeconomics 12: 201-225.

Turvey R. 1964. Optimization and suboptimization in fishery regulation. Am Econ Rev 54: 64-76.

UNEP. 2004. Analyzing the resource impact of fisheries subsidies: a matrix approach, United Nations Environment Program.

Vieites Baptista de Sousa JM. 2014. El sector conservero de pescados y mariscos de Galicia: evolución de su impacto socioeconómico, internacionalización e innovación, ANFACO-CECOPESCA, Vigo.
Waldo S, Paulrud A. 2016. Reducing greenhouse gas emissions in fisheries: the case of multiple regulatory instruments in Sweden. Environ Resour Econ 68: 275-295.

Waldo S, Jensen F, Nielsen M, Hellefsen H, Hallgrimsson J, Hammarlund C, Hermansen Ø, Isaksen J. 2016. Regulating multiple externalities: the case of Nordic fisheries. Mar Resour Econ 31: 233-257.

Weber P. 1994. Net loss: fish, jobs and the marine environment, Worldwatch Inst., Washington.

World Bank, FAO 2009. The sunken billions: the economic justification for fisheries reform, Agriculture and rural development series, World Bank, Washington DC, Rome.

Xunta de Galicia. 2014. Estadísticas Pesca de Galicia, Plataforma tecnoloxíca da pesca [WWW Document]. URL http://www. pescadegalicia.gal/estadisticas.html (accessed on: 2016/01/02).

Xunta de Galicia. 2015. Ocupesca: Enquisa sobre a poboación ocupada nos sectores da pesca e da acuicultura mariña en Galicia 2013.

Cite this article as: Merayo E, Waldo S, Nielsen M. 2018. Impact of a simultaneous reduction in fishing subsidies and introduction of efficient management of rents: the case of the Northwest Spanish fleet. Aquat. Living Resour. 31: 1 